\title{
MONITORING THE LEVEL OF HEAVY METALS POLLUTION IN AUTOMOBILE MECHANIC WORKSHOPS USING TREE BARKS
}

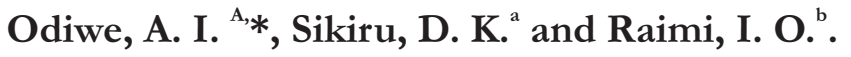 \\ ${ }^{a}$ Department of Botany, Obafemi Awolowo University, Ile-Ife, Nigeria. \\ ${ }^{\mathrm{b}}$ Institute of Ecology and Environmental Studies, Obafemi Awolowo University, Ile-Ife, Nigeria. \\ *Corresponding Author's email address and Phone number: aiodiwe@oauife.edu.ng; 07034394721. \\ (Received: $17^{\text {th }}$ April, 2018; Accepted: $17^{\text {th }}$ August, 2018)
}

\section{ABSTRACT}

\begin{abstract}
The level of heavy metals at automobile mechanic workshops were monitored by examining tree barks of different species and influence of sampling heights on the metals level. This was with the aim of determining the suitability of using tree barks in monitoring the level of air pollution. Tree bark samples were collected at 2 and 4 $\mathrm{m}$ heights from different automobile mechanic workshops around Ile-Ife metropolis and at control sites. The samples were transported to the laboratory, oven-dried at $60{ }^{\circ} \mathrm{C}$ to a constant weight; ground and analyzed for $\mathrm{Pb}, \mathrm{Cu}, \mathrm{Cd}, \mathrm{Fe}$ and $\mathrm{Zn}$ using Atomic Absorption Spectrophotometer. Results showed that the concentration of $\mathrm{Fe}, \mathrm{Cu}$ and $\mathrm{Pb}$ at the mechanic sites were significantly $(\mathrm{p}<0.001)$ higher at $2 \mathrm{~m}$ than $4 \mathrm{~m}$ height in all the species. The concentration of $\mathrm{Zn}$ was significantly $(\mathrm{p}<0.001)$ higher at the $2 \mathrm{~m}$ height in all the sites except for Gliricidia sepium. The concentration of Cd was however, significantly $(\mathrm{p}<0.05)$ higher at the control site at the two heights for the species except for Gliricidia sepium and Terminalia catappa, that showed no significant difference $(p>0.05)$ between the sites. The correlation value of 0.94 was observed between $\mathrm{Zn}$ and $\mathrm{Cd} ; 0.76$ between $\mathrm{Pb}$ and $\mathrm{Cd}$, and 0.50 between $\mathrm{Zn}$ and $\mathrm{Pb}$. This study showed that different species have different affinities for air pollutants and that soil particles also acted as a source of heavy metals in our environment.
\end{abstract}

Keywords: Atmospheric, Automobile, Pollutants, Soil particle, Trace metals, Tree barks

\section{INTRODUCTION}

Environmental pollution is one of the biggest problems facing the world; it is a big global issue that is affecting man and our environment today. Rapid urbanization, industrialization, and phenomenal increasing population are major factors causing environmental pollution in the world. These activities have led to corresponding increases in atmospheric concentration of primary and secondary pollutants (Mage et al., 1996). The different parts of biosphere are impacted upon negatively by different inorganic and organic contaminations because of manmade activities and this modify the normal biogeochemical nutrients cycling (Mahanta and Bhattacharyya, 2011; Montoneri et al., 2014). Heavy metals are characteristic parts of the earth, they are released into the atmosphere in various ways, i.e. transportation, industry, petroleum products, agriculture, and other man-made activities (Butkus and Baltrenaite, 2007; Cayir et al., 2008). Automobiles constitute one of the major modes of transportation for conveying people and goods in many nations of the world; the usefulness of this mode of transportation is not without its negative impact. Pollutants from the exhaust of motor vehicles represent $60-70 \%$ of the contamination found in urban area (Tripathi and Gautam, 2007).

The discharge of pollutants at varying concentrations into environments (air, soil and water) needs to be monitored and controlled regularly. Biomonitoring method has been extensively used as a tool for assessing environmental pollution (Olowoyo et al., 2010; Odiwe et al., 2014). In biomonitoring, living species are used to monitor toxic metal pollution in the environment. Plant species, like moss, lichen, pine barks and pine needles have been extensively used for monitoring atmospheric pollution. This is because they are very easy to handle, readily available and more convenient (Olowoyo et al., 2010). Generally, there is no consensus on the unique species that is suitable as biomonitors of trace metal pollutants all over the world, though trees with rough barks have been found to be more effective (Santamaria and Martín, 1997; El-Hasan et al., 2002). For this reason, different species have been used and still being used as bio-monitors in different parts of the world. Among these bio-monitors, tree bark is 
known to absorb and accumulate airborne contaminants and has therefore been used for monitoring of atmospheric pollution (Odukoya et al., 2000; Olowoyo et al., 2010). It has been reported that airborne pollutants are mostly accumulated in the outer bark of trees (Harju et al., 2002).

Schelle et al. (2006) pointed out that it is possible to use tree barks from different species in similar environmental bio-monitoring studies. Conti and Cecchelti (2001) has reported that there are different mechanisms of accumulation of elements from the environment (atmosphere) which include particulate trapping, ion exchange, extracellular electrolyte sorption, hydrolysis, and intracellular uptake. In Nigeria, the general practice is that automobiles are taken to roadside mechanics by the users for either repair or general maintenance work. Most of these auto mechanic workshops are usually located in areas where trees such as Spondias mombin (Anacardiaceae), Terminalia catappa (Combretaceae), Gliricidia sepium (Fabaceae) and Senna siamea (Fabaceae) can provide shade. From previous literature, it has been established that tree barks of different plant species found at the workshops may accumulate the pollutants that are released into the atmosphere (Ojekunle et al., 2015; Agboola et al., 2016).

Generally, studies on air pollution caused by automobile workshops are available (Wong and Lau 1985; Iwegbue, 2007; Ipeaiyeda and Dawodu 2008), but there is a need for continuous research with the use of tree bark for biomonitoring, not just because of the negative effect on the bark but also the indirect effect on humans that rely on these barks for medicinal purposes. Studies using the above-mentioned trees have not been carried out to determine their suitability in assessment of trace metals in the environment (atmosphere). Therefore, this study was carried out to assess the suitability of the back of different tree species that were not previously reported as biomonitors of toxic trace metals found at the mechanic workshops in Ile-Ife, Osun State, Nigeria.

\section{MATERIALS AND METHODS}

\section{Study Area}

The study was carried out in eight different mechanic workshops situated in Ile-Ife metropolis $\left(7^{0} 29^{\prime} 42.3^{\prime \prime} \mathrm{N}\right.$ latitude and $4^{0} 28^{\prime} 30^{\prime \prime} \mathrm{E}$ longitude) in Osun State, southwestern Nigeria. The study sites were chosen based on the presence of these trees, the various activities at the workshop and the distance to the main road. The geographical locations (geo-reference) of the study sites were obtained using a Global Positioning System (GPS).

The description of the climate, soil and the vegetation of Ile-Ife have been given in details in our earlier published work (Odiwe et al., 2012). Most of the original lowland rainforests have been destroyed leaving remainder of secondary forest scattered around. The actual age of the trees cannot be ascertained but most of the trees were not less than 10 years based on the information gathered from the operators/owners of the mechanic workshops, the mean yearly temperature of the study site is $25.5{ }^{\circ} \mathrm{C}$ with an average yearly precipitation value of $1302 \mathrm{mmyr}^{-1}$ (OAU APRG, 2015). The description and details of the sites are given in table 1. 
Table 1: Location, Elevation and Coordinates of the Different Study Sites in Ile-Ife, Nigeria.

\begin{tabular}{|c|c|c|c|c|}
\hline Site & Description & Elevation & Latitude & Longitude \\
\hline 1. & $\begin{array}{l}\text { Located around Lagere road in Ile-Ife and has been in use } \\
\text { for over } 15 \text { years. Spraying, rewiring and welding are } \\
\text { common activities at the site. Gliricidia sepium is present }\end{array}$ & $296 \mathrm{~m}$ & N07029.369' & E04033.707' \\
\hline 2. & $\begin{array}{l}\text { Located along the same area and similar activities as in site } \\
1 \text { are performed at this site. Gliricidia sepium also present }\end{array}$ & $301 \mathrm{~m}$ & N07029.396' & E04033.676' \\
\hline 3. & $\begin{array}{l}\text { The site is located very close to site } 1 \text { and } 2 \text {, around Lagere } \\
\text { area, Spraying, rewiring and welding are common activities } \\
\text { and the tree species found at the site is Senna siamea. }\end{array}$ & $289 \mathrm{~m}$ & N07029.501' & E04033.549' \\
\hline 4. & $\begin{array}{l}\text { Located along Lagere road in a busy city center of the town } \\
\text { and extensively used. The shade tree species found in this } \\
\text { site is Spondias mombin. }\end{array}$ & $263 \mathrm{~m}$ & N07029.330' & E04032.242' \\
\hline 5. & $\begin{array}{l}\text { Located at Olurin Street, Ondo road round about. The site } \\
\text { has been in existence for over } 12 \text { years and the activities at } \\
\text { this site are auto -mobile repair, welding, spraying of parts, } \\
\text { panel beating, vulcanizing. The tree species found in this site } \\
\text { is Senna siamea }\end{array}$ & $313 \mathrm{~m}$ & N07027.633' & E04033.242 \\
\hline 6. & $\begin{array}{l}\text { Along Ondo road, heavy vehicle/trailer/ trucks are repaired } \\
\text { here. Soil at this site is highly polluted going by the very dark } \\
\text { soil colour. The tree species found in this site is Terminalia } \\
\text { catappa. }\end{array}$ & $303 \mathrm{~m}$ & N07027.654' & E04033.159' \\
\hline 7. & $\begin{array}{l}\text { Located along Ondo road, it shares the same major road as } \\
\text { site } 6 \text { but located about the tail end of the road. Activities } \\
\text { noticed in this site are panel beating, engine repairs, } \\
\text { servicing and spraying. Tree species found at this site is } \\
\text { Terminalia catappa. It is about } 2 \mathrm{~km} \text { to site } 6\end{array}$ & $264 \mathrm{~m}$ & N07029.064' & E04032.139’ \\
\hline 8. & $\begin{array}{l}\text { The site is along Ondo road. Activit ies at this site are } \\
\text { automobile engine repairs, panel beating, vulcanizing, } \\
\text { spraying. Refuse burningis also common. Spondias mombin is } \\
\text { present here. }\end{array}$ & $264 \mathrm{~m}$ & N07029.063' & E04032.137’ \\
\hline
\end{tabular}

\section{Sample Collection and Analyses}

The trees used in this study were planted as shade plants around the workshops; with nothing less than six stands of the same species at the workshops. Six to eight trees of approximately the same girth size from each of the workshops were used in the study. Tree bark samples were collected from the tree species present in each of the automobile mechanic workshops (Table 1). For the control site, samples of tree barks of the same species found in the mechanic sites were collected at the Obafemi Awolowo University (OAU) Botanical Garden, Ile-Ife which is reasonably free from automobile pollution activities (about $4 \mathrm{~km}$ to the closest site where experimental samples were taken).

Tree bark samples were collected at approximately $2 \mathrm{~m}$ (Barnes et al., 1976) (to assess effect of soil particles) and $4 \mathrm{~m}$ above the soil (to assess the pollutants). The tree bark samples were obtained by utilizing a properly washed stainless steel knife and washed after each collection with $10 \% \mathrm{HNO}_{3}$ to avoid contamination. The collection was done during dry season and they were replicated six times. The samples were collected around the whole diameter of the trees. The bark samples were parked in a plain white paper, put in a polythene bag and taken to the laboratory. The samples collected were oven-dried at $60{ }^{\circ} \mathrm{C}$ to a constant weight, ground into powdery form and analyzed for the presence of the following heavy metals: $\mathrm{Cu}, \mathrm{Pb}, \mathrm{Zn}, \mathrm{Fe}$ and $\mathrm{Cd}$ using the method described by Tel and Rao (1982).

\section{Statistical Analysis}

Two-way ANOVA was used to compare the level of heavy metals in the polluted sites (automobile mechanic workshop) and unpolluted site (control site), and at the two heights ( $2 \mathrm{~m}$ and $4 \mathrm{~m}$ ) in each of the species. The significant means are separated using a post hoc analysis (LSD). The statistical analysis was done using SAS 9.3 model. 


\section{RESULTS}

\section{Concentration of Iron}

The concentration of $\mathrm{Fe}$ in the polluted sites (mechanic workshops) was significantly $(\mathrm{p}<$ 0.001 ) higher at $2 \mathrm{~m}$ compared with the $4 \mathrm{~m}$ height in all the species (Figure 1). From the $2 \mathrm{~m}$ height, the concentration ranged from $92.83 \pm 4.30$ to $110.49 \pm 3.21 \mathrm{ppm}$; and $84.84 \pm 2.21$ to $111.22 \pm$ 6.19 ppm at the $4 \mathrm{~m}$ height.

\section{Concentration of Copper}

The concentration of $\mathrm{Cu}$ followed similar trend like that of $\mathrm{Fe}$, where the concentration in all the species was significantly $(p<0.001)$ higher in the polluted sites (mechanic workshops) at $2 \mathrm{~m}$ height compared with the $4 \mathrm{~m}$ height (Figure 2). From the $2 \mathrm{~m}$ height, the concentration ranged from $4.26 \pm$ 0.08 to $5.72 \pm 0.18 \mathrm{ppm}$; and $3.73 \pm 1.13$ to $5.29 \pm$ $1.21 \mathrm{ppm}$ at $4 \mathrm{~m}$ height.

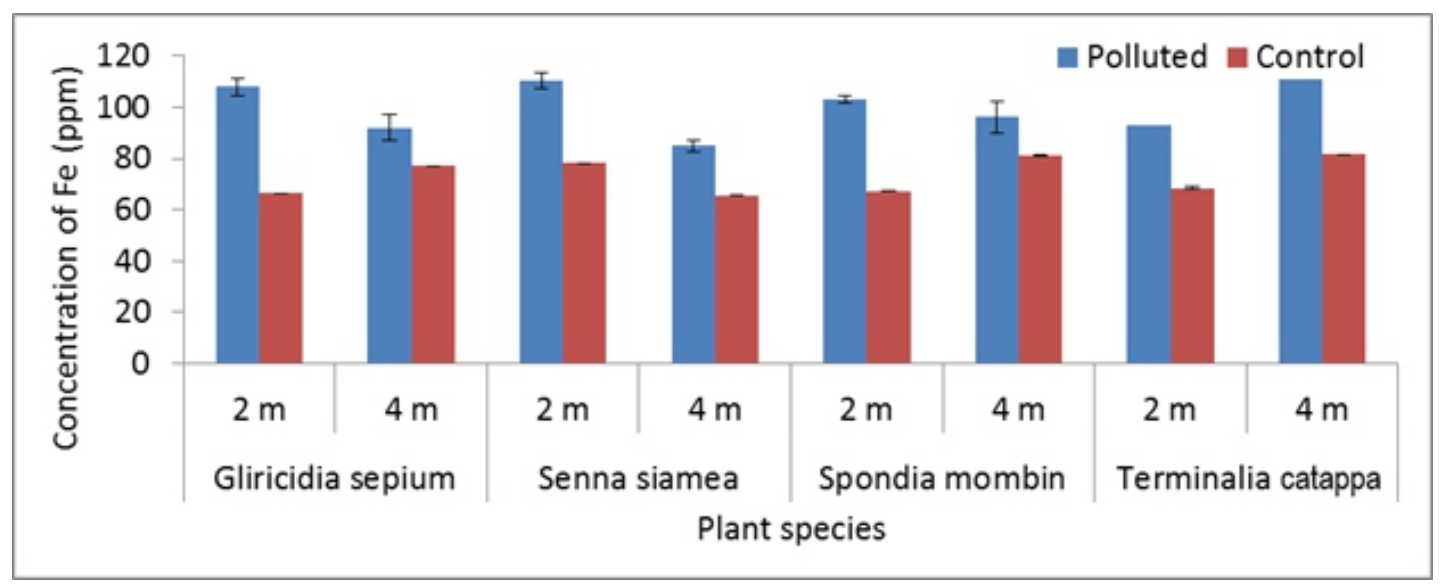

Figure 1: Mean Concentration of Fe in the Control and Polluted Sites across the Species and between the Heights. Bars on the column represent the standard error of the mean, $n=6$.

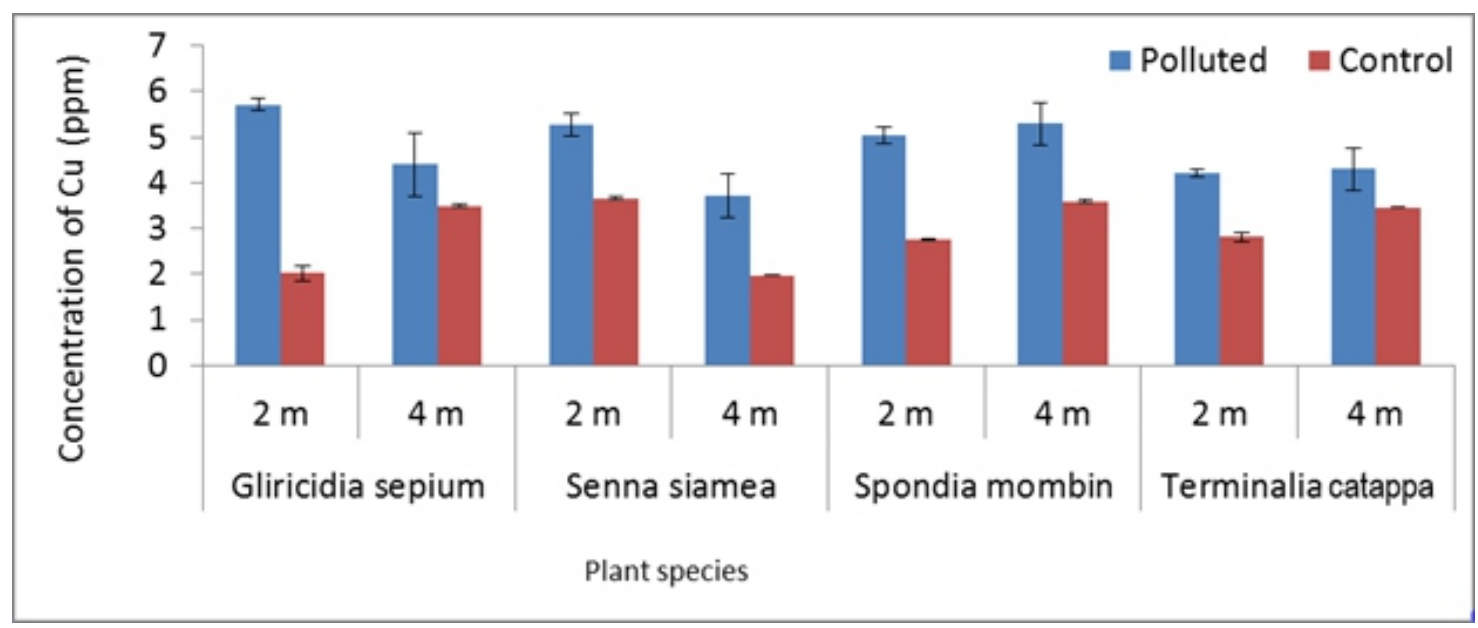

Figure 2: Mean Concentration of Cu both in Control and Polluted Site across the Species and between the Heights. Bars on the column represent the standard error of the mean, $n=6$.

\section{Concentration of Zinc}

The concentration of $\mathrm{Zn}$ in the analyzed tree barks in all the species (Figure 3) revealed that the polluted sites was significantly $(p<0.001)$ higher compared with control site at the $2 \mathrm{~m}$ height in all the species except for Gliricidia sepium species, where control was higher at $4 \mathrm{~m}$ height; and in
Terminalia catappa where there was no significant ( $\mathrm{p}$ $>0.05)$ difference between the control and polluted sites. From the $2 \mathrm{~m}$ height, the concentration of $\mathrm{Cd}$ ranged from $55.52 \pm 3.82$ to $59.55 \pm 0.26 \mathrm{ppm}$; and $27.43 \pm 2.14$ to $55.07 \pm$ $2.49 \mathrm{ppm}$ at the $4 \mathrm{~m}$ height. 


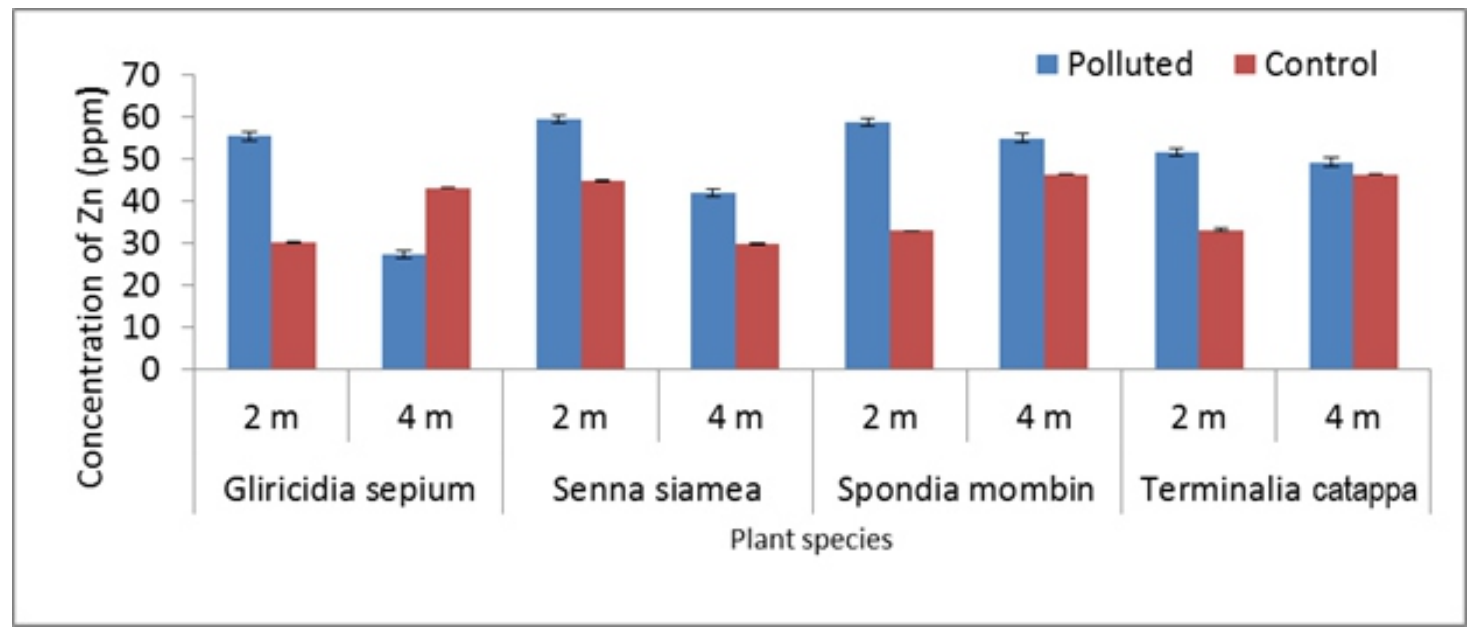

Figure 3: Mean Concentration of Zn both in Control and Polluted Site across the Species and between the Heights. Bars on the column represent the standard error of the mean, $n=6$.

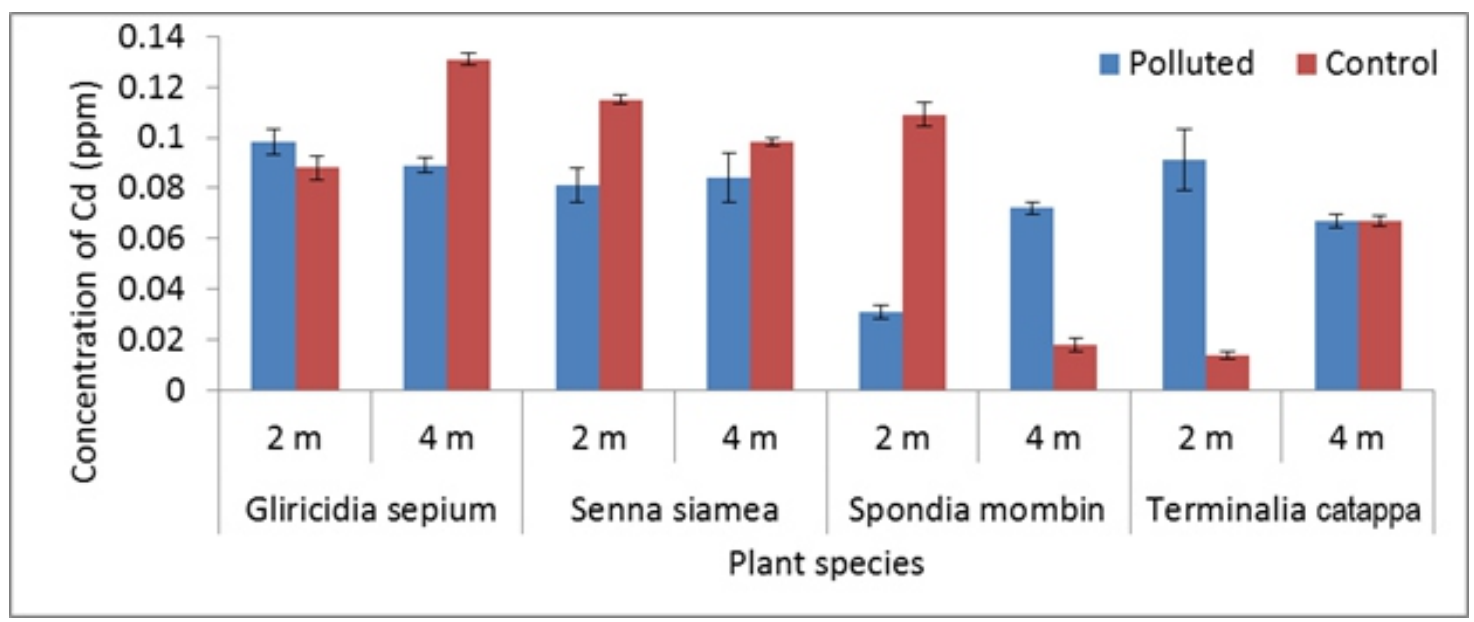

Figure 4: Concentration of Cd both in Control and Polluted Site across the Species and between the Heights. Bars on the column represent the standard error of the mean, $n=6$.

\section{Concentration of Cadmium}

The concentration of Cd was significantly $(\mathrm{p}<$ 0.05) higher at the control site compared to the polluted sites in all the species at the two heights except for G. sepium and T. catapa, where there was no significant difference ( $\mathrm{p}>0.05)$ between the polluted and the control at $2 \mathrm{~m}$ and $4 \mathrm{~m}$ heights respectively (Figure 4). It should however be noted that, the concentration of $\mathrm{Cd}$ in the polluted sites was significantly $(p<0.05)$ higher in Spondias mombin at $4 \mathrm{~m}$ height and in T. catappa at 2 $\mathrm{m}$ height. From the $2 \mathrm{~m}$ height, the concentration of $\mathrm{Cd}$ ranged from $0.03 \pm 0.01$ to $0.11 \pm 0.01$ ppm; and $0.07 \pm 0.01$ to $0.09 \pm 0.01 \mathrm{ppm}$ at the 4 m height.

\section{Concentration of Lead}

The concentration of $\mathrm{Pb}$ in all the species was significantly higher in the polluted sites compared with the control at the two heights except for Terminalia catappa where there was no significant difference between the control and the polluted $(\mathrm{p}$ $<0.05$ ) at the $2 \mathrm{~m}$ height (Figure 5). From the $2 \mathrm{~m}$ height, the concentration of $\mathrm{Pb}$ ranged from 0.07 \pm 0.01 to $0.26 \pm 0.02 \mathrm{ppm}$; and $0.06 \pm 0.02$ to 0.18 $\pm 0.03 \mathrm{ppm}$ at the $4 \mathrm{~m}$ height. 


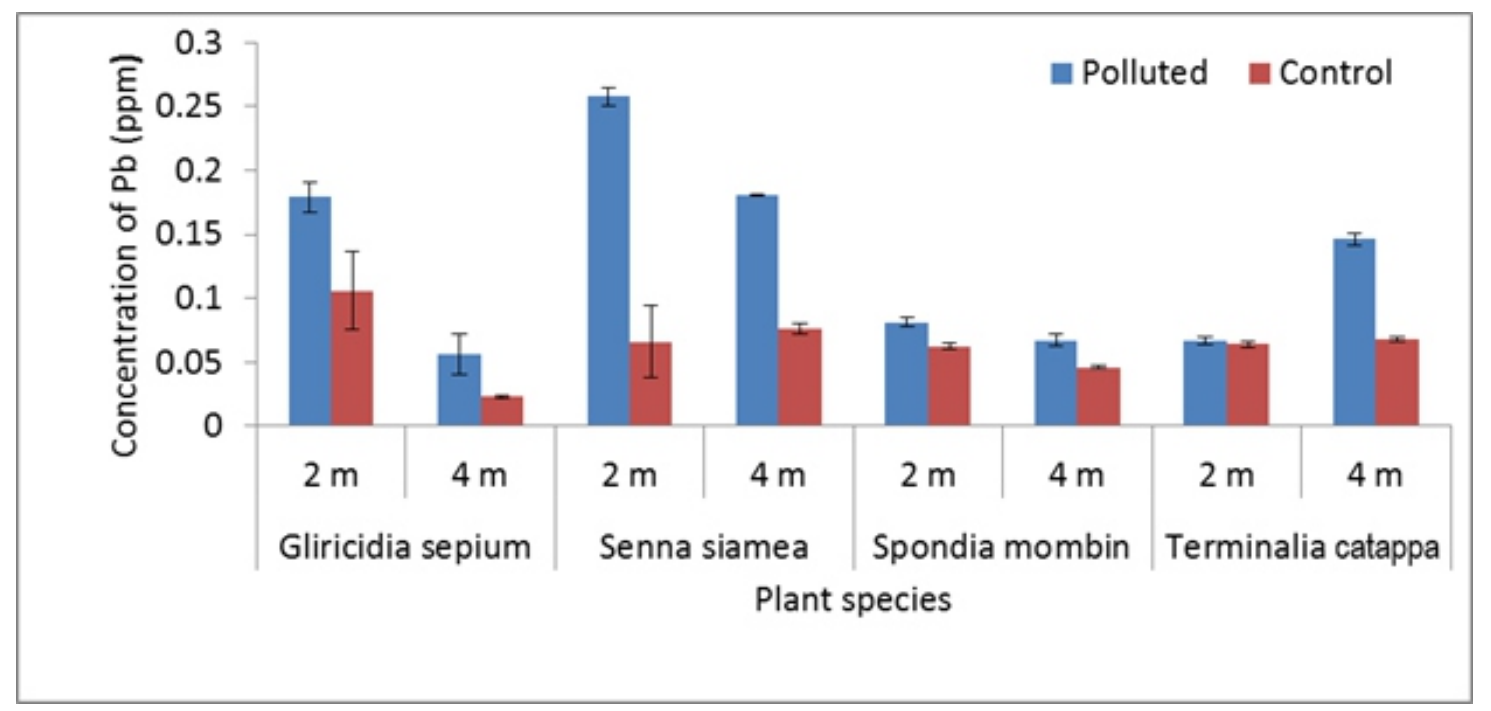

Figure 5: Concentration of $\mathrm{Pb}$ both in Control and Polluted Site across the Species and between the Heights. Bars on the column represent the standard error of the mean, $n=6$.

Relationship between heavy metals at both heights and across the sites

Pearson correlation coefficient was used to establish if there was any relationship between level of heavy metals in the samples from the sites at both $2 \mathrm{~m}$ and $4 \mathrm{~m}$ height (Table 2). It was obvious from the matrix that there was a positive and strong correlation among elements that are associated with vehicular emission. The positive high correlation values of $0.94,0.76$, and 0.50 were observed between $\mathrm{Zn}$ and $\mathrm{Cd}$; $\mathrm{Pb}$ and $\mathrm{Cd}$; and $\mathrm{Zn}$ and $\mathrm{Pb}$ respectively (Table 2 ).

Table 2: Correlation values showing the relationship between the trace metals across the study sites

\begin{tabular}{|c|c|c|c|c|c|}
\hline Heavy metals & $\mathrm{Fe}$ & $\mathrm{Zn}$ & $\mathrm{Cu}$ & $\mathrm{Cd}$ & $\mathrm{Pb}$ \\
\hline $\mathrm{Fe}$ & 1 & & & & \\
\hline $\mathrm{Zn}$ & 0.30 & 1 & & & \\
\hline $\mathrm{Cu}$ & -0.21 & -0.99 & 1 & & \\
\hline $\mathrm{Cd}$ & -0.05 & 0.94 & -0.97 & 1 & \\
\hline $\mathrm{Pb}$ & -0.68 & 0.50 & -0.58 & 0.76 & 1 \\
\hline
\end{tabular}

\section{DISCUSSION}

\section{Concentration of Iron}

The higher level of Fe obtained at the automobile workshops compared to control site in this study showed that Fe is linked to activities like repair, burning and maintenance services at the workshops. This finding is consistent with results of Ademoroti (1990); Olowoyo et al. (2010): Mbong et al. (2014) and Odiwe et al. (2014) where higher $\mathrm{Fe}$ concentration at the polluted sites compared with unpolluted area was reported. The higher values recorded at the lower height $(2 \mathrm{~m})$ close to the ground surface compared to higher height $(4 \mathrm{~m})$ across the sites give an indication that soil/dust particles also serve as a source of heavy metals in our environment. This observation is in agreement with the findings of Frati et al. (2005) and Ho and Tai (1998) who reported that the occurrence and distribution of Fe as pollutants in the environment originate mainly from soil particles. 


\section{Concentration of Copper}

The pattern of increased concentration of $\mathrm{Cu}$ observed at both heights for the polluted sites compared with the control sites in this study might be associated to some extent with automobile repair activities at the sites. The source of $\mathrm{Cu}$ may be due to corrosion of metallic parts of cars derived from engine wear, thrust burning, brushing and bearing metals, scrap batteries and other parts at the mechanic workshops (Odiwe et al., 2014). Olowoyo et al. (2010) in their study have also reported that the sources of $\mathrm{Cu}$ were related to corrosion of metallic parts of cars derived from engine wear, thrust burning and other activities around the polluted sites.

\section{Concentration of Zinc}

The higher concentration of $\mathrm{Zn}$ just like $\mathrm{Pb}$ and $\mathrm{Cu}$ recorded at the automobile mechanic sites compared with the control site at both heights might be linked with repair and maintenance activities at the sites. The accumulation of lead recorded in this study might be as a result of numerous activities involving lead and its products that are carried out by the automobile technicians. These activities include spray painting, panel beating, metal cutting, radiator repair, battery charging, and welding as well as repair works by mechanic. This observation is consistent with the findings from other studies (Nyle and Ray, 1999; Elik, 2003; Khan et al., 2011). The average concentration of $\mathrm{Zn}$ from the two sites (at both heights) (27.42-55.51 ppm) is very low compared to the acceptable value of $300 \mathrm{mg} / \mathrm{kg}$ (Faiz et al., 2009); and the values of $410 \mu \mathrm{g} / \mathrm{g}$ and $715 \mu \mathrm{g} / \mathrm{g}$ reported for $\mathrm{Zn}$ from studies conducted in Jordan and China respectively.

\section{Concentration of Cadmium}

The higher concentration of $\mathrm{Cd}$ in the control site compared with the polluted site in this study contradicts the general belief that $\mathrm{Cd}$ release is associated with combustion products in the carburetors of motor vehicles (Divrikli et al., 2006). However, the present result did not show that the level of this trace element in all the sites is associated with automobile related activities. Though, metal production and refining are additionally known to be a source of cadmium discharge into the atmosphere as well as during manufacture of batteries (Al-Khashman and
Shawabkeh, 2009). However, the higher level obtained at the control sites indicates the level of the metal in the soil. Cadmium is also known to be an inevitable by-product of zinc, lead and copper and it is also found in manures and pesticides which may be the case for samples collected from the botanical garden. The level of $\mathrm{Cd}$ from this study (0.02 - $0.13 \mathrm{ppm}$ was lower than the values reported by Olowoyo et al. (2010) in Pretoria (0.121.34) and Odiwe et al. (2014) in Ile-Ife.

\section{Concentration of Lead}

The higher concentration of $\mathrm{Pb}$ recorded at the polluted sites compared with the control at both heights might be related to the volume of vehicles that come for repair and maintenance activities. This might suggest anthropogenic source for the metal. Sources of $\mathrm{Pb}$ in the environment have been pointed out to include soil and dust from combustion of gasoline that contains tetraethyl lead as anti-knock agent (Tuzen, 2003). Burning of fossil fuels and traffic has also been reported to contribute to the high level of $\mathrm{Pb}$ (Al-Khashman, 2007). Olowoyo et al. (2010) in their study also reported that high level of $\mathrm{Pb}$ was obtained from sites with high traffic. Report from other researchers suggested a long history of metal contamination in urban environment due to resuspension which may in turn account for the presence of $\mathrm{Pb}$ in the environment (Li et al., 2001). The results obtained in this study are comparable to heavy metal concentrations obtained by Ho and Tai (1998), who found that concentration of various heavy metals in urban city of Hong Kong are high. They correlated high $\mathrm{Pb}$ level with higher traffic density and the extent of aerial deposition volume of heavy metals. The level of $\mathrm{Pb}$ recorded at the mechanic workshops in this study is consistent with the findings of Lukashev et al. (1994); Lippo et al. (1995) and Poikolainen, (1997) in Europe, where $\mathrm{Pb}$ concentration of the barks have been reported to be in the range of $<5 \mathrm{ppm}$ and even in some places, $<1 \mathrm{ppm}$ ).

\section{Relationship between the heavy metals across the sites at the two heights}

The strong correlation coefficient for some of these metals may imply that these elements might have originated from the same source which in this case could be linked to vehicular emission and automobile repair activities at the various sites in 
this study area. The correlation coefficient recorded for these metals in this study is in agreement with the results of Faiz et al. (2009), who also reported a positive correlation for the metals in their study. The poor correlation values for some of the other metals ( $\mathrm{Fe}$ and $\mathrm{Cu} ; \mathrm{Fe}$ and $\mathrm{Cd}$ and $\mathrm{Fe}$ and $\mathrm{Zn}$ ) might indicate that the metals are not from the same source (automobile pollution) but rather from some other sources (Table 2). Generally, the higher concentration of the pollutants at the lower height $(2 \mathrm{~m})$ compared with the upper height $(4 \mathrm{~m})$ simply indicates that soil particles played a major role in the levels of the pollutants recorded in this study. This observation is consistent with the findings of Huhn et al. (1995) and Schulz et al. (1999) who reported that concentration of heavy metals in tree barks is generally found to be a function of heavy metals deposition.

\section{CONCLUSION}

The heavy metals concentration in the tree barks gave a clear indication that trees found in automobile mechanic workshop might have been bio accumulating some metal pollutants. The tree barks were found to be a good bio-indicator of trace metals like $\mathrm{Fe}, \mathrm{Pb}, \mathrm{Zn}$, and $\mathrm{Cu}$; which are the most pronounced elements detected in the tree barks at the automobile workshops. The variation in the concentration of heavy metals between the sites studied and across the tree species might be due to volume of automobile repair and maintenance activities at the sites. This study has also shown that dust samples may be a potential source of the heavy metals in our environment in addition to vehicular activities. It is therefore recommended that planting of trees should be encouraged in automobile workshops so as to help in the reduction of the pollutants through absorption thereby making the air quality of these premises better. Automobile workshops should also be cited in places that are not close to public or residential area.

\section{ACKNOWLEDGEMENT}

This is to acknowledge the assistance of $\mathrm{Mr}$. Bennard Omomoh of the Department of Botany, Obafemi Awolowo University, Ile-Ife who helped in the identification of the plants species. We also want to appreciate the support of an anonymous reviewer who helped in proofreading the manuscript and made some useful suggestions.

\section{REFERENCES}

Agboola, O.O., Orji, D.I., Olatunji. O.A. and Olowoyo, J.O. 2016. Bioaccumulation of Heavy Metals by Moringa Oleifera in Automobile Workshops from three Selected Local Governments Area, Ibadan, Nigeria. West African Journal of Applied Ecology 24(1) 9-18.

Ademoroti, C.M.A. 1990 Bio-accumulation of Heavy Metal in some Mangrove Fauna and Flora. In: Environmental Chemistry and Toxicology Consultancy, Benin, pp. 180-182.

Al-Khashman, O.A and Shawabkeh, R.A. 2009. Metal distribution in urban soil around steel industry beside Queen Alia Airport, Jordan. Environmental Geochemistry and Health 31:717-729.

Al-Khashman, O.A. 2007. The investigation of metal concentrations in street dust samples in Aqaba city, Jordan Environmental Geochemistry and Health 29:97-207.

APRG (Atmospheric Physics Research Group) 2015. Department of Physics and Engineering Physics, Obafemi Awolowo University, Ile-Ife,

Barnes, D., Hammadah, M.A. and Ottaway, J.M. 1976. The lead, copper, and zinc contents of tree rings and barks, a measurement of local pollution. Science of the Total Environment 5:63-7.

Butkus, D. and Baltrenaite, E. 2007. Transport of heavy metals from soil to Pinus sylvestris Linn. and Betula pendula trees. Ekologija 53:29-36.

Cayir, A, Coskun, M. and Coskun, M. 2008. Concentrations of some elements in the bioindicator organism Cladonia rangiformis collected at the vicinity of Canakkale. Ekolojï 69:7-13.

Conti, M. E. and Cecchetti, G. 2001. Biological monitoring: lichens as bioindicators of air pollution assessment-a review. Environmental Pollution 114:471-492

Divrikli, U., Horzum, N., Soylak, M. and Elci, L. 2006. Trace heavy metal contents of some spices and herbal plants from western 
Anatolia, Turkey. International Journal of Food Science and Technology. 41:712-716.

El-Hasan, T., Al-Omari, H., Jiries, A., and AlNasir, F. 2002. Cypress tree (Cupressus semervirens L.) bark as an indicator for heavy metal pollution in the atmosphere of Amman City, Jordan. Environment International Journal28:513-519.

Elik, A. 2003. Heavy metal accumulation in street dust samples in Sivas. Communication in Soil Science and Plant Analysis 34:145-156.

Faiz, Y., Tufail, M., Javed, M.T., Chaudhry, M.M. and Naila-Siddiqu. 2009. Road dust pollution of $\mathrm{Cd}, \mathrm{Cu}, \mathrm{Ni}, \mathrm{Pb}$ and $\mathrm{Zn}$ along Islamabad Expressway, Pakistan. Microchemical. Journal92(2):186-192.

Frati, L., Brunialti, G. and Loppi, S. 2005. Problems related to lichen transplants to monitor trace element deposition in repeated surveys: a case study from Central Italy. Journal of Atmospheric Chemistry 52:221-230.

Harju, L., Saarela, K.E., Rajander, J., Lill, J.O., Lindroos, A. and Heselius, S.J. 2002. Environmental monitoring of trace elements in bark of Scots pine by thicktarget PIXE. Nuclear Instruments and Methods in Physics Research Section B 189:163167.

Ho, Y.B. and Tai, K.M. 1998. Elevated levels of lead and other metals in roadside soil and grass and their use to monitor aerial deposition in Hong-Kong. Environmental. Pollution 49:37-51.

Huhn, G., Schulz, H., Stark, H.J., Tolle, R. and Schuurmann, G. 1995. Evaluation of regional heavy metal deposition by multivariate analysis of element contents in pine tree barks. Water, Air and Soil Pollution 84:367-383.

Ipeaiyeda, A.R, and Dawodu, D. 2008. 'Heavy metals contamination of topsoil and dispersion in the vicinities of reclaimed auto-repair workshops in Iwo Nigeria'. Bulletin of the Chemical Society of Ethiopia 22(3):339-348.

Iwegbue, C.M. 2007. 'Metal fractionation in soil profiles at automobile mechanic waste dumps around Port Harcourt'. Waste Management Resources 25(6):585-593.

Khan, M.N., Wasim, A.A., Sarwar, A. and
Rasheed, M.F. 2011. Assessment of heavy metal toxicants in the roadside soil along the N-5, National Highway, Pakistan. Environmental Monitoring and Assessment 182: 87-595.

Li, X., Poon, C.S. and Liu, P. S. 2001. Heavy metal contamination of urban soils and street dusts in Hong Kong. Applied Geochemistry 16:1361-1368.

Lippo, H., Poikolainen, J. and Kubin, H. 1995. The use of moss, lichen and pine bark in the nationwide monitoring of atmospheric heavy metal deposition in Finland, Water, Air and Soil Pollution 85(4):2241-2246.

Lukashev, M.E., Sheppard, D. and Pytela, R. 1994. Disruption of integrin function and induction of tyrosine phosphorylation by the autonomously expressed beta 1 integrin cytoplasmic domain. Journal of Biological Chemistry 269:18311-18314.

Mage, D., Ozolins, G., Peterson, P. and Webster, A. 1996. Urban Air Pollution in Megacities of the World. Atmospheric Environment 30(5):681-686.

Mahanta, M.J. and Bhattacharyya, K.G. 2011. Total concentrations, fractionation and mobility of heavy metals in soils of urban area of Guwahati, India. Environmental Monitoring Assessment 173:221-240.

Mbong, E.O., Akpan, E. E. and Osu, S.R. 2014. Soil-plant heavy metal relations and transfer factor index of habitats densely distributed with Citrus reticulata (tangerine). Journal of Research in Environmental. Science and Toxicology 3(4):6165.

Montoneri, E., Tomasso, L., Colajanni, N., Zelano, I., Alberi, F, Cossa, G.and Barberis R. 2014. Urban wastes to remediate industrial sites: a case of polycyclic aromatic hydrocarbons contamination and a new process. International Journal of Environmental Science and Technology 11:251-262.

Nyle, C.B and Ray, R.N. 1999. The Nature and Properties of Soils. 12th ed. United States of America pp. 743-785.

Odiwe, A.I., Adesanwo-Adeyemi, T.J., Olowoyo, J.O. and Raimi, I.O. 2014. Assessment of trace metals using lichen transplant from automobile mechanic workshop in Ile-Ife 
metropolis, Nigeria. Environmental Monitoring Assessment 186 2487-2494.

Odiwe, A.I., Ogunsanwo, O, and Agboola, O.O. 2012. Impact of re-forestation of a regrowth Secondary forest with Tectona grandis (1.) Ten years after on understory species composition and distribution in IIe-Ife, southwestern Nigeria. Ife Journal of Science 14(1): 109-121

Odukoya, O.O., Arowolo, T.A. and Bamgbose, O. 2000. Lead, $\mathrm{Zn}$ and $\mathrm{Cu}$ levels in tree barks as indicator of atmospheric pollution. Environment International 26:11-16.

Ojekunle, Z. O., Ubani, D. R., Sangowusi, R. O. 2015. Effectiveness of neem, cashew and mango trees in the uptake of heavy metals in mechanic village, Nigeria. African Journal of Environmental Science and Technology 9(2):136-142,

Olowoyo, J.O., van Heerden, E. and Fischer, J.L. 2010. Investigating Jacaranda mimosifolia tree as biomonitor of atmospheric trace metals. Environmental Monitoring and Assessment 164:435-443.

Poikolainen, J. 1997. Sulphur and heavy metal concentrations in Scot Pine bark in Northern Finland and Kola Peninsula," Water, Air and SoilPollution 9:395-408.

Santamaria, J.M. and Martin, A. 1997. Tree bark as a bioindicator of air pollution in Navarra, Spain, Water, Air and Soil Pollution 181:25-
30.

Schelle, L.M., Gallo, M.V., Denham, M. and Ravenscroft, J. 2006. Effects of pollution on human growth and development: an introduction. Journal of Physiological Anthropology 25:103-12.

Schulz, H., Popp, P., Huhn, G, Stark, H.J. and Schuurmann, G. 1999. Biomonitoring of airborne inorganic and organic pollutants by means of pine tree barks. I. Temporal and spatial variations. Science of the Total Environment 232:49-58.

Tel, D. and Rao, P. 1982. Automated and semiautomated methods for soil and plant analysis. IITA Manual Series No.7 International Institute of Tropical Agriculture, Ibadan, Nigeria. pp 1-33.

Tripathi, A.K. and Gautam, M. 2007. Biochemical parameters of plants as Indicators of air pollution. Journal of Environmental Biology 28:127-132.

Tuzen, M. 2003. Determination of heavy metals in soil, mushroom and plant samples by atomic absorption spectrometry. Microchemistry Journal 74:289-297.

Wong, M.H. and Lau, W.M. 1985. Root growth of Cynodon dactylon and Eleusine indica collected from motorways, at different concentrations of lead. Environmental Research 36: 257-267. 